\title{
The transition from academic to workplace writing: Students talk about their experiences
}

\author{
Jo-Anne Andre and Barbara Schneider \\ University of Calgary, Faculty of Communication and Culture
}

This article reports on a study of the transition from university to workplace writing as experienced by students in a co-operative education work placement programme. Informed by the concept that writing is social in nature, this study supports a genre based analysis of the writing and the transitions made by the students in the programme. Issues of writerly identity are addressed. As well, this article engages in the ongoing debate about the value of explicit genre instruction, concluding that such instruction is important, especially given the implications and costs of errors in using workplace genres.

L'article fait rapport d'une étude portant sur la transition entre l'écriture du milieu universitaire et celle du milieu de travail telle que vécue par les étudiants participant à un stage de travail dans le cadre d'un programme de coopération en éducation. L'étude, informée par une compréhension de la nature sociale de l'écriture, favorise une analyse de la transition achevée par des étudiants inscrits au programme en termes d'une étude des genres. Les questions d'identité d'écriture sont également passées en revue. De plus, l'article s'engage dans le débat qui entoure la question de la valeur d'un enseignement explicite des genres et conclue que cet enseignement est important compte tenu du coût des erreurs commises en utilisant les genres propres au milieu de travail.

I thought of myself as a good essay writer. I didn't think of myself as a good writer. When you get into a work term, it doesn't matter how good of an essay you can write, because... that's not what you need in the workplace.

— Sheila, a 4th year Communications student 
The ability to write an academic essay, as Sheila points out in recounting her experiences of writing in a work term, is "not what you need in the workplace." But within Shelia's straightforward assertion lie a number of complex constructs- notions of writer identity, questions of genre acquisition, and the rhetorical demands of different writing contexts - that come into play when we look at how new writers negotiate writing tasks in the workplace. In this article, we contribute to the growing literature on students' transitions to the workplace with a report of an exploratory study that interrogated the experiences of nine university students from three disciplines in work term placements that required them to write on the job. Drawing on research on the transitions of new writers and on insights about the social nature of writing provided by genre theory, we situate the students' experiences in the context of a number of key differences between writing in the classroom and writing in the workplace that produce challenges for students as they make the transition to workplace writing. Our study focused on two research questions:

1. How much and what kind of writing are students called upon to do in work terms?

2. How do students experience the transition from school-based to workplace writing?

Underlying these questions are two main concerns: how do novice writers in organizations acquire written genres and learn to negotiate the social practices in their production, and how can post-secondary institutions best equip students to take on these roles successfully? We begin by reviewing literature in two areas: the transition experiences of novice workplace writers and genre theory. We then discuss some key differences between classroom writing and workplace writing. After a brief description of our research method, we describe the writing our students did and analyze their experiences in the transition to writing in the workplace. We conclude from our exploratory study that the classroom does have role to play in preparing students for the writing they will do in the workplace, and we end with a consideration of implications for the way writing is taught within universities.

\section{Theoretical Context}

A number of studies have examined the transition experiences of novice workplace writers. Anson and Forsberg (1990) found that interns pass through a number of stages as they adapt to a new workplace environment. They characterize these stages as expectation, disorientation, and transition and resolution. Lutz (1989) and McKinnon (1993) focussed on how novices learn the local purposes and writing 
practices of a new setting. In her study of communication graduate students, Lutz (1989) found that novices use a variety of strategies to learn the ropes: conversing with others and reading print materials they are given (e.g. company brochures, employee manuals, and style guides); actively seeking out information and questioning others; observing individuals and interactions in their workplaces; studying rhetorical models and participating in document planning meetings. New workers also rely heavily on feedback both directly from colleagues and supervisors (Lutz, 1989) and in the document cycling process (McKinnon, 1993) to accommodate to the writing demands of the workplace. McKinnon (1993) also found that to write well in an organization, new employees had to learn a good deal about the business functions performed by their departments, the jobs performed by their readers, and the values and beliefs implicit in the organization's activities (p. 45-46). In an extensive study of academic and workplace writing, Dias, Freedman, Medway, and Pare (1999) suggest that writers need to learn not only the new genres of the workplace but also new ways to learn those genres (see also Freedman \& Adam, 2000).

As this literature makes clear, developing competence in workplace writing requires much more than simply learning the formal features of the particular genres used in a workplace. Genre theory can help us to understand why this is so. Genre theory is an approach that regards writing as ultimately social in nature. Writing is always shaped by writers' understandings of the communicative action required by particular situations. Writers call on the conventions of specific genres to accomplish specific communicative purposes. Genres are thus not just sets of textual regularities but rather forms of "social action" (C. Miller, 1994 [1984]), "complex patterns of repeated social activity and rhetorical performance arising in response to a recurrent situation" (Paré \& Smart, 1994, p. 146). According to Paré and Smart (1994), textual genres embody a distinctive profile of regularities across four dimensions: a set of texts, the composing processes involved in creating these texts, the reading practices used to interpret them, and the social roles performed by writers and readers (p. 147).

Genre theory is helpful in illuminating the experiences of students as they make the transition to the writing demands of the workplace, particularly some of the difficulties they face. If genres are socially situated, then "genres serve as keys to understanding how to participate in the actions of a community" (Miller, 1984, p. 165). Workers cannot write as literate members of a community unless they know the language and understand the role of writing in "various social, administrative, and managerial processes" (Anson \& Forsberg, 1990, p. 203). In learning how and when to use the genres of a workplace, new members learn the norms and social roles as well as the composing practices of that workplace. Thus it is never sufficient to know the 


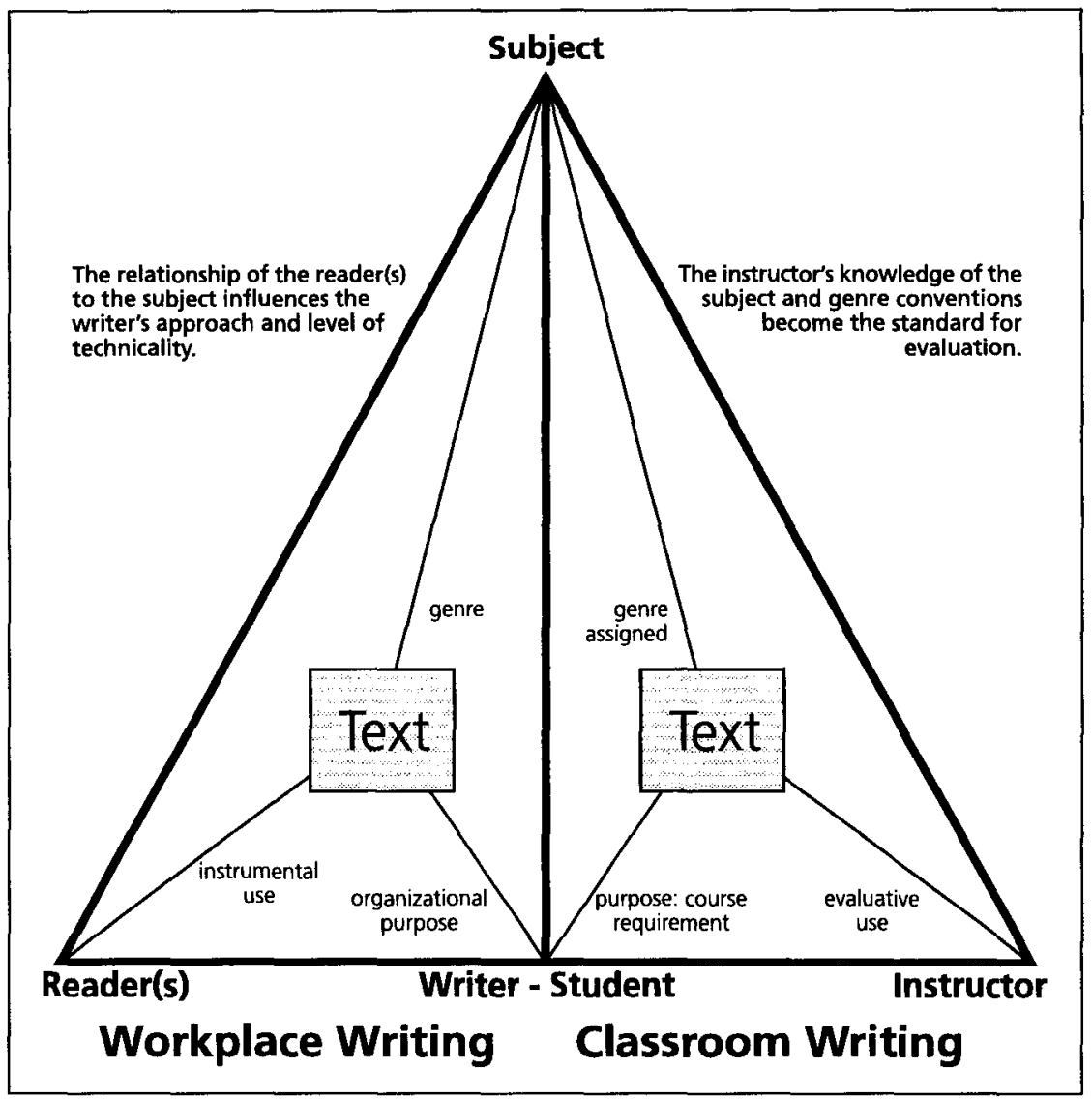

Figure 1: Writing in the Workplace vs Writing in the Classroom.

textual features of ideal forms of a genre, although that is of course necessary. As Dias et al. (1999) point out, "one needs to understand and take on the local purposes that prevail in that setting" (p. 22).

\section{Writing in the classroom vs. writing in the workplace}

In making the transition from the local purposes of academia to the local purposes of the workplace, writers must adapt to radical changes in context, changes that profoundly affect why and what they write, how they conceptualize their audiences, how they compose and structure their documents, and how they construct their identities as writers. Of the many striking differences between writing in the classroom and writing within workplace settings, some key differences stand out; these relate to complexity of the social context, the role of written genres, the nature of composing processes, readers' and writers' purposes, and the writer's sense of identity (see Figure $1^{1}$ for a summary of these differences). 


\section{Complexity of Social Context}

Writers in organizational or workplace settings must deal with a rich and multilayered context (Dias, Freedman, Medway, \& Paré, 1999; Driskill, 1989). Besides focusing on their own purposes for writing and their audience's needs, they must negotiate the influences of the organization's structure, web of social relationships, history, culture, and image, and sometimes too the larger economic, legal, and social considerations that enter into their work. In contrast, when students write for teachers, their writing is embedded in a thin social context; they seldom write with extra-textual considerations beyond assignment deadlines, their instructor's expectations, and the grade they hope to achieve.

\section{Readers' and Writers' Purposes}

Writers' and readers' purposes also differ dramatically between academic and non-academic settings. In school settings, students write to complete assignments and to earn grades; their audiences - usually only their instructors-read their writing almost exclusively for pedagogical and evaluative purposes. Even when instructors specify a hypothetical audience and attempt to read as that audience, their ultimate purpose is still the same-to evaluate the writing. In workplaces, in contrast, writers write to accomplish real instrumental goals, both personal and organizational, and they write to audiences who themselves have instrumental reasons motivating their reading. And readers in the workplace read documents quite differently from the way instructors read students' texts (Freedman, Adam, \& Smart, 1994). For example, Souther (1963) showed that managers seldom read reports in their entirety, unlike instructors, who feel obligated to read student assignments from beginning to end. Not only do readers' purposes and reading practices differ significantly between academic and non-academic settings, but what readers in these two contexts consider acceptable or competent writing also varies a great deal (Haswell, 1991; Leonard \& Gilsdorf, 1990).

\section{Composing Proccesses}

Composing processes also differ significantly. Academia typically values independent work and punishes the use of others' writing as plagiarism. Students are expected to do their own work without input from others, and the writing process ends once the writing is marked. Even when students work collaboratively on group projects, they receive grades that go onto their individual records. In contrast, workplace writing is embedded in social relationships, both inside and outside the organization. Writers often borrow freely from existing documents written by others in the organization, and document cycling, in which writers rewrite documents in 
response to feedback from others in the organization, continues the writing process until the document meets organizational requirements for an acceptable document. Organizations typically call upon writers to produce genres with tightly prescribed formats, and a particular genre is selected because the organization has a history of using that genre to accomplish particular communicative purposes. However, genres are prescribed not because there is a "correct" way to structure documents but as a way to maintain consistency of content and style in organizational presentation. Student writers, in contrast, although they are also typically assigned prescribed genres (e.g., the essay, the book review, the summary, etc.) with specified formats, are assessed on how well they meet the instructors expectations for the genre rather than on how well they accomplish any larger communicative purpose.

\section{Writer Identity}

Finally, students writing for instructors in academic contexts seldom escape a subordinate position, as they almost always must write to an audience who not only is required to evaluate their work but who knows more than they do, if not about their immediate subject then about the best way to structure their texts and to express their ideas. In contrast, writers within organizational settings are more likely to write from a position of expertise. In addition, writers in organizations must assume various organizational personae in order to carry out organizational business. Writers in academia, on the other hand, are encouraged to see themselves as objective researchers taking a neutral stance toward the knowledge they write about.

\section{Research method}

To investigate how novice writers manage the differences between academic and workplace writing, we interviewed nine third- and fourth-year university studentsthree from Communication Studies, three from Management, and three from Political Science. The students were randomly chosen from a list of participants in a university co-operative education program in which they typically alternate their academic studies with up to six paid work-term placements. All but two students were in their early 20s, all had English as their first language and five of the nine were female. Their most recent work term placements included federal and provincial government departments, transportation and tourism organizations, a resource company, and a charitable organization, as indicated in Table 1. In this article, we refer to all student participants by pseudonyms.

Our study was an exploratory case study. We did not set out to test specific hypotheses but rather to explore the writing experiences of a small group of students in work term placements. We interviewed each student once, using a semi-structured 


\section{Table 1: Students' Writing in their Work Term Placements, by} Discipline

\begin{tabular}{|c|c|c|c|}
\hline Sudent & Hortorom INT p & $\begin{array}{l}\text { The spent } \\
\text { wiling }(\%)\end{array}$ & Willing Iosis or genres \\
\hline \multicolumn{4}{|c|}{ Communication Studies Students } \\
\hline $\begin{array}{l}\text { diend } \\
\text { thlyear }\end{array}$ & 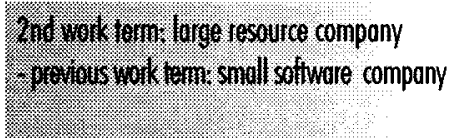 & & $\begin{array}{l}\text { Iles' monual } \\
\text { Its } \\
\text { Itorns }\end{array}$ \\
\hline $\begin{array}{l}\text { reany } \\
\text { lit year }\end{array}$ & 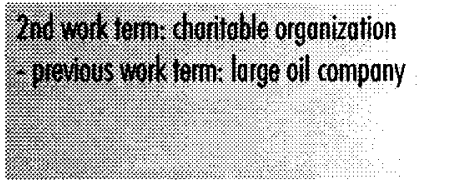 & \% & 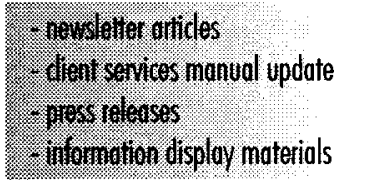 \\
\hline Sheilo & 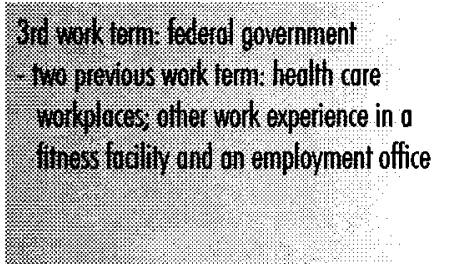 & 13. & 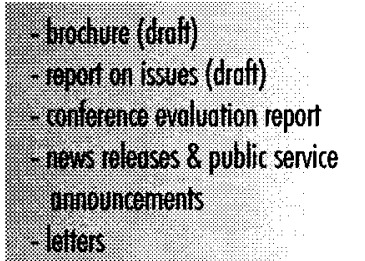 \\
\hline \multicolumn{4}{|c|}{ Management Students } \\
\hline lee & 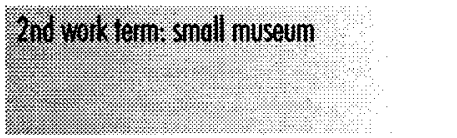 & 25\% & $\begin{array}{l}\text { ols for children } \\
\text { uctions, }\end{array}$ \\
\hline intor & 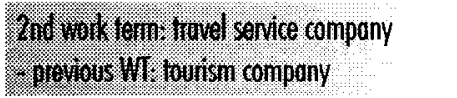 & 81. & 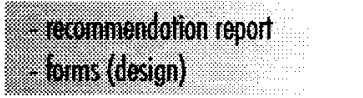 \\
\hline ming & 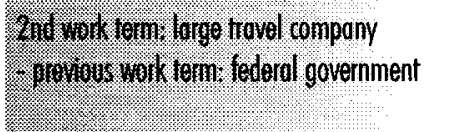 & & 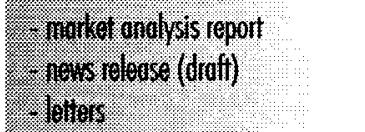 \\
\hline \multicolumn{4}{|c|}{ Political Science Students } \\
\hline $\begin{array}{l}\text { This } \\
\text { 4hear }\end{array}$ & 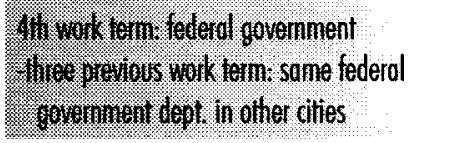 & $70 \%$ & 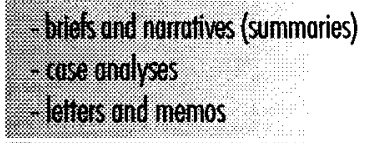 \\
\hline $\begin{array}{l}\text { Hovin } \\
\text { thlyear }\end{array}$ & 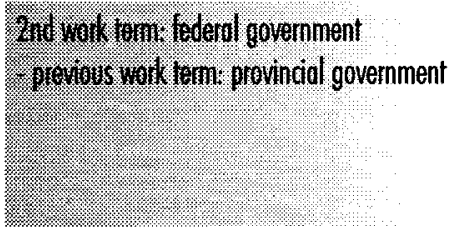 & $65.70 \%$ & 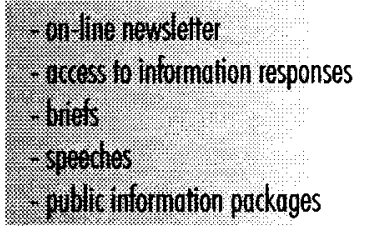 \\
\hline $\begin{array}{l}4010 \\
\text { Oro veor }\end{array}$ & 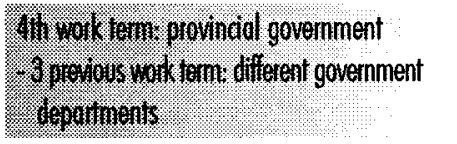 & & 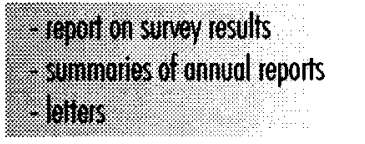 \\
\hline
\end{tabular}


interview format in which we asked a set of pre-determined questions (see Appendix A), from which we occasionally digressed to ask additional questions to follow up on specific responses. In cases where the students brought along samples of the workplace writing they had done, we reviewed the documents with the students. We took notes on the interviews, which we also taped (with students' written consent) and transcribed. Our method of data analysis draws on the grounded theory approach of Glaser and Strauss (1967). We studied our notes and transcripts for recurring themes and patterns in the students' experiences, organized our findings into a framework provided by our discussion of the differences between academic and workplace writing, and elaborated these categories with illustrations from our data.

\section{Students' writing in the workplace}

Our interviews confirmed that students can expect to write a great deal and to produce a variety of documents in their workterms. On average, the students we interviewed spent close to $60 \%$ of their work time on writing or writing-related tasks. As Table 1 shows, the Political Science students reported spending an average of $78 \%$ of their work time on writing, followed by the Communications students, who averaged $65 \%$, and then Management students, who spent on average $42 \%$ of their time writing.

In their work terms, these students produced a remarkably wide range of textual genres. They composed news releases, memos, letters, forms, summaries and briefs, case analyses, newsletters, brochures, access to information responses, speeches, instructions, manuals, major reports, and educational and informational materials and displays. Besides the variety of genres, the sheer size of some of the documents these students produced is worth noting: in her work term as a technical writer, Cheryl turned out a 300-plus page manual, and Kevin described researching and writing a 100-page report in one of his work terms for the government.

As Twyla observed, in the workplace, research and writing tasks are often delegated downwards. While most writing that the students did in the workplace was assigned to them, some students noted that they took the initiative to propose research and writing projects. For example, when Rick saw the outdated technology in his workplace, he took the initiative, with his supervisor's support, to research and write a major report studying possible technological innovations. Kevin also reported initiating a new genre in his workplace-a weekly online bilingual newsletter, which he edited and for which he also wrote occasional pieces. 


\section{Students' Experiences of the Transition to Workplace Writing}

We expected that students on work terms might experience problems in their transition to workplace writing, particularly if they privileged their own purposes and formal generic knowledge rather than attending adequately to the organizational norms for genres, to the rhetorical situation, and to the larger organizational and social context. In fact, we found that for the most part, our students adapted well to the workplace, "jumping," as Dias et al. (1999) put it, "into the rhetorical pool and swimming" (p. 173). However, they all found that they did have to adjust to the specific requirements of the workplaces they found themselves in. The differences in rhetorical demands within the classroom and within workplace settings discussed above provide a framework for our discussion of our students' successes and the challenges they faced in making the transition to workplace writing. We also discuss two additional areas, editorial standards and style and the role of feedback in the workplace.

\section{Adapting to Complexity of Context}

Rick's experiences dramatize the transition to the complex social context of work, particularly the need to understand organizational culture in order to grasp rhetorical situation. Rick describes himself as a competent writer who within the scope of his work term came to understand the organizational realities in his workplace and to respond to them effectively. The organizational culture, he said, is "very bureaucratic... there's a lot of red tape, and it's pretty patriarchal, ... things are pretty slow to move." When asked how these considerations influenced the decisions he made in writing a report recommending the adoption of a technological innovation, he responded, "It made a big difference, and actually it took another employee to point this out to me.... My approach had to be a lot more qualitative, a lot more incremental." To gain widespread support for his report's recommendations, he consulted workers who would be affected by his recommendations and attempted to make a case for his innovation that relied less on a quantitative, financial "pay-back" analysis and more on a qualitative discussion of the benefits of the proposed innovation.

But Rick also understood that the administrators who would be reading his report had their own, very quantitative organizational subculture. In order for his innovation to be accepted, he also had to satisfy the needs of upper management for "more numbers." Ultimately, Rick succeeded in persuading his audience, who advised him that that they planned to implement his recommendations. As a fourthyear Management student, Rick had brought a certain kind of professional expertise with him into his work term placement; as he put it, he could "calculate eight million different kinds of pay-back." But he found he had to call upon a lot more than technical skills and formal genre knowledge if he was to write a report that would succeed in 
persuading his co-workers and supervisors to accept his recommended course of action. As Rick's case shows, even cultural differences within organizations must, of necessity, affect the strategy in writers' documents. And, since Rick's report recommended a technological innovation within a workplace that had long resisted such innovation, his report carried within it seeds of change that might eventually reshape the very organizational culture that had challenged him as a writer.

\section{Understanding Readers' and Writers' Purposes}

In their workplace writing, students had to adapt to a new understanding of both readers' and writers' purposes. Cheryl, for example, compared the expanded role that audience plays in workplace writing compared to academic writing:

One of the biggest things is audience.... [When] you're writing for a professor, ... you're not really writing to anybody; when you get into the job, that's one of the first things you have to know, who you're writing to. It comes up all the time in the level of detail, the level of information that has to happen in the documents. Who's going to be looking at them is [the] number one [consideration].

While we might want to take issue with Cheryl's contention that when you write for a professor "you're not really writing to anybody," she points to an important difference between academic and workplace writing contexts, namely that readers in academia read to evaluate rather than for an instrumental purpose.

Lynne's work term experiences also taught her the importance of understanding who she was writing for and why. In one work term with a provincial government department, she saw her writing improve dramatically once she better understood her audience and the rhetorical purpose of her documents. In that job, she interviewed clients and then wrote summaries of the interviews for social workers. When she first started, she did not understand what the summaries would be used for, so she wrote too much and did not include the right information. Once she understood how case workers used the summaries to make certain kinds of decisions, she was able to produce more effective and more concise summaries, and she found that she no longer had to revise. Chris had a similar experience in his work term with the federal government. He had to write narratives in which he summarized the historical events leading to the present situation. If he strayed from his assigned task of simply providing historical background by offering analysis or other comments on the material, he was told by his supervisor to "leave it out." His supervisor wanted research, not analysis. Rick demonstrated his awareness of the multiple audiences for workplace documents in describing how he approached his report. He says he made 
a point of including background information because "you don't know who's going to read it. Anyone should be able to pick it off the shelf and understand what you are saying." Lee, in his work for a small museum, learned to test the educational materials he produced on his intended audiences and revise in response to the feedback he received.

\section{Composing Processes}

Not only did the students we interviewed have to adapt to a new understanding of how audiences shape documents, they also discovered that composing processes in the workplace are deeply embedded in larger social relations and patterns of social interaction. Cheryl, describing a workplace in which she was employed as a technical writer, noted the complicated pattern of collaborative writing and document review in the production of manuals. In producing the manuals, she had to work with both the R \& D and engineering departments; she explained,

we all have our own chapters or manuals that we're responsible for. At every release level, documents get reviewed by the boss and by other writers, then it goes out to the associated departments. All this before anything ever gets to the end user.

Penny found that it was not enough to write good press releases and public service announcements. She also had to gain rapport with media people in order to get her writing out to its intended audience of the general public. Lee, in his work for a small museum, learned to test the educational materials he produced on his intended audiences and revise in response to the feedback he received.

Most students found that their workplaces had prescribed formats to follow for particular kinds of documents, which they learned by using existing documents as models. In his work with the government, Chris used a previous student's work as a model for the briefs he wrote. Cheryl used company templates for the various chapters of the instruction manual she wrote so that "everything kind of looks the same." Twyla also used a company template for report writing and used samples of news releases provided by her work term supervisor as models for her own news releases.

\section{Writer Identity: Assuming an Organizational Persona and Perspective}

A somewhat unpleasant surprise for the students in our study was the degree to which they were expected to give up the academic ideal of the objective researcher and writer and instead take on an organizational persona and privilege organizational purposes and perspectives in their writing. Sometimes the students' conflicts 
revolved around the ways in which their audiences within the organization expected them to select information and to "spin" or interpret it in their documents. Chris, who worked in the litigation section of a federal government department, was surprised in his first work term with that department to find that in preparing legal briefs and summaries for his department's staff, he was expected to look not for "facts" but for arguments to support the government's position in the litigation. As Freedman, Adam, and Smart (1994) remind us, "genres ascribe to those involved distinct personae and social roles" (p. 196). In this case, Chris had to discard the persona of the objective researcher that had served him well as a Political Science student to assume the particular persona and perspective demanded by the genre he was called upon to produce as a government employee.

Occasionally, student writers were made uncomfortable when they had to balance the conflicting demands of internal readers and external audiences. Kevin had to perform this difficult juggling act when, as part of his job working for a federal government department, he had to respond to access to information requests. In handling this genre, he came to realize that he was expected to protect the reputation of the government but also appear to be giving out information-a position that he found uncomfortable and stressful and that prompted him to reflect on whether he was violating his own moral principles. Dias et al. (1999) encapsulate our students' difficulties, pointing out that professionalization often comes at a cost to self-identity. Writers may have to "do things as professionals that they are not prepared to do as persons" (p. 234). Sheila in her work term also was forced into a position in which she had to abandon an objective view of the facts and to privilege a certain organizational version of reality when she was forced to rewrite a conference evaluation report. She recalls,

I wrote a very objective report-what was good and what was bad and what could be improved-and it actually got ix-nayed [rejected] and I had to rewrite it because it was going to a director to get funding again for a project next year.

The upper level administrator who demanded that Sheila rewrite the report felt that a more positive evaluation of the conference would be more likely to attract continued government funding. Sheila was surprised to have to rewrite her report as she believed that her original report was superior. In fact, at the end of her work term, when she had to submit a report to the university showing the kind of work she did on the job, Sheila chose to hand in her original evaluation report rather than the rewritten version. 
These three students were put in sometimes difficult positions as they took on the role of writing from the perspective of the organizations in which they were working. Commenting on her particular rhetorical situation in writing to a government audience, Sheila observed, "With the government... you have to be very careful what you write and what you say. It was very, well, political." Her words aptly capture not only her own experience but that of Chris and Kevin as they negotiated the challenges of reflecting the government's purposes and perspectives as they wrote for both internal and external audiences.

\section{Editorial Standards and Style}

The students also had to adjust to organizational writing styles and editorial standards. Most of the students we interviewed found that they had been overconfident as writers entering the workplace. Not only did the complex political and social realities of the workplace cause them occasional grief, but the red pen wielded by their supervisors made them realize that the standards for writing in the workplace were generally higher than those they had experienced in university. Cheryl, a Communications student who now works as a technical writer at the large resource company where she did her final work term, noted, "the first hard thing that I realized was the difference between handing in an assignment to my professor and [to]... my supervisor... [is that in the workplace] your documents have to be excellent all the time, perfect or near perfect; you have to keep achieving that." In the workplace, she says, "misplaced punctuation and commas really do matter a lot, and that's not drilled into your brain enough in university at all."

Several students noted the stylistic value accorded conciseness in workplace writing compared with academic writing, in which they often felt compelled to stretch out their ideas to "fill up pages." The students also talked about the differences they perceived in the latitude for personal style and creativity in writing in academic and non-academic settings. Most of the students felt that writing style seemed to matter more in workplace writing. Chris, a Political Science student, was surprised to get comments on his writing style in the workplace, feedback he says he never got from his professors. Sometimes, he says, his supervisor complimented his writing style, while at other times, he was asked to rewrite.

Many of the students felt that in the workplace, personal writing style was restricted. As Cheryl put it,

you can write as an individual when you're writing a [university] term paper. You can say what you want and phrase it the way you want; when you get into an organization, you're really streamlined, more so than I 
ever thought and there's many ways to say something, but this is [one firm's] way and this is [another firm's] way, and you have to... it becomes your own style.

In contrast, Rick noted what he saw as greater freedom in workplace writing:

I guess you tend to apply the standard template type of approach in a school atmosphere... but it does tend to take some imagination, expressiveness, the ability to really apply it because you know you have this template that you should be adhering to in order to ensure a decent mark. In the real world, I keep the template in mind, but I'm much more liable to alter it and mould it and fix it the way I like it to fit my situational variables.

Kevin felt his creativity constrained in both his university writing and in the writing he did in the workplace, where, he says, he tried to find room for creativity in his work by adding his own touches. He says that, in academic writing, while "every person has a different way of thinking, profs have only one way of marking and giving an A... To get a good mark, students should not be too original."

Some students noted that the stylistic latitude they enjoyed in the workplace depended on who was supervising them and on where they worked. In her second work term as a technical writer, Cheryl found that she had "a lot of flexibility and input," something she didn't have in her previous work term, where, she says, "it was more 'this is what we want and how we want it."

\section{The Role of Feedback}

Feedback from supervisors was critical in helping these student writers learn the local genre conventions and to respond to the particular rhetorical situations they faced. Over and over again, the students in our study talked about feedback as the key strategy for adapting and helping them to understand what to include and what not to include-as Penny put it, "what to say and what not to say"-in their documents. However, students noted a difference between feedback in academic and non-academic settings. "In the workplace," says Cheryl, "feedback comes everyday, constantly." In university, on the other hand, feedback on writing usually comes only once a piece of writing is completed; in their experience, feedback at this point is less effective and students "don't learn from it."

Sheila failed initially to produce an acceptable report from her organization's point of view because she did not fully understand the real purpose and audience for her report. Feedback from supervisors was essential in helping her to gain a full un- 
derstanding of audience and purpose. Penny recounts that she relied heavily on her supervisors in all her work terms to catch on to each situation. She said, "you have to smile a lot for the first few days and ask a lot of questions" to get the idea of each writing context. Rick notes that his supervisor gave him good advice on how to adapt his ideas for his audience, and, as a result, his confidence rose.

However, when students got conflicting feedback from different supervisors or when they failed to get any feedback, they became frustrated. When Lynne was asked to write a report compiling the results from a survey, a change in supervisors, each of whom had different ideas about how the report should be structured, left Lynne feeling unclear about how to approach the report. And when Kevin turned in writing that failed to elicit any feedback, he became frustrated; in such cases, he says, he felt that his writing just went into a black hole and he never knew how he was doing.

\section{Conclusions and Implications for Teaching}

As this study makes clear, being a good writer in a workplace involves much more than simply knowing the genres of that workplace. It also requires an understanding of the complex social realities and communicative purposes of each particular situation. While we agree with Dias et al. (1999) that it is not possible to simulate the complexities of a real social context in the classroom, we do not share their pessimistic view that workplace genres cannot be successfully taught in the classroom. We believe that the classroom does have role to play in preparing students for the writing they will do in the workplace. We suggest that in order to develop competence in workplace writing, writers must (1) become familiar with the basic formal conventions of various workplace genres; (2) understand and learn to enact genres as contextualized rhetorical strategies that take into account local norms, social roles, and composing practices; and (3) benefit from feedback on their performance.

\section{Formal genre conventions}

We believe that explicit instruction in workplace genres plays an important role in familiarizing students with the basic formal features of non-academic genres. We found no evidence of "overlearning or misapplication" of formal genre knowledge, a possible risk identified by Freedman (1994, p. 195) in articulating an argument against explicit teaching of genre. Despite the wide variety of genres and the prescribed formats for the genres that the students were called upon to produce, the interviews revealed that the students experienced no real conflict between the genres they produced in the workplace and the nonacademic document formats they had learned in school. Without exposure to particular document forms, students are unlikely to tacitly learn the formal conventions of such genres before entering the workplace. While 
tacit learning (Freedman 1994) can occur once students are immersed in the workplace, such learning-typically through trial and error-can be very slow. In our study, students who learned by trial and error reported feeling that they had inadequate knowledge of how to approach some of the genres they were asked to produce.

We might also consider the social and other costs that come into play when tacit learning detours through the landscape of error. While the "error" in the trial-anderror method of genre acquisition in academic writing is measured in terms of grades (in our study, both Lynne and Penny, for example, reported getting a D in their first English papers and then through consultation and practice improving their grades), the "error" in workplace writing can accrue more serious costs, not just loss of selfesteem and confidence on the part of the writer but, potentially, damage to a company's image, loss of credibility, and even financial loss. Explicit instruction of basic formal features of non-academic textual genres can provide a foundation or a schema upon which students can build further as they refine their local understandings of genre production within a specific context.

\section{Knowledge of how genres function as contextualized social action}

When instructors teach writing, they must take care to do so within a framework that emphasizes the socially situated nature of written genres. Explicit teaching of the formal features of textual genres must also be informed by an understanding and acknowledgement of the variation in form exhibited by genres within different contexts. Students should also be introduced to composing strategies that can increase the probability of their success as they learn to enact genre as a contextualized rhetorical strategy in their workplace writing. The students in our study, for example, reported turning to supervisors, co-workers, textbooks and other reference materials, and models from workplace files in order to get more information about specific genres. In particular, students learning about workplace genres within academic contexts should be encouraged to reflect on the limits of such instruction, on the ways in which workplace writing forms can never be fully captured in writing instruction and practice within the classroom.

In all programs of academic study, students should be encouraged to take advantage of educational programs that allow them to complete internships or work terms in their field. One of the Communications Studies students we interviewed, Cheryl, suggested that perhaps such programs should be made mandatory. Whether they are mandatory or optional, such placements afford students the opportunity to come to a fuller understanding of contextualized genre through experience in a real workplace. However, to ease students' transition and to optimize the benefits they gain from such work experience, academic programs would do well to implement 
writing internship courses that students would take during their work terms (e.g. Anson \& Forsberg, 1990; Lutz, 1989; Smart, 2000). Such courses could provide a forum for students to discuss work-related drafts, editorial matters, and discourse conventions of non-academic writing genres. Freedman (1994) notes that "teaching... during an internship provides an ideal locale" for certain kinds of explicit genre instruction since "students are involved in authentic tasks and authentic contexts when the teaching takes place" (p. 205). An internship course could offer students rich opportunities for reflective practice; students in such a course could be asked to do assignments reflecting on the writing they are doing, the range of texts they see in the workplace, and the kind of feedback they get on their writing. In such a course atmosphere, students could learn from each other's experiences and could come to a fuller practical and theoretical understanding of the social action of writing in the workplace. Through such classes, students in all fields can gain a new perspective on their own development as writers and can begin to see themselves as possessors of a kind of expertise that fuses practical expertise with theoretical knowledge.

\section{Feedback on performance}

Finally, to develop competence as a writer, feedback appears to be essential. Writers acknowledge the value of feedback, whether it is positive or negative and whether it addresses aspects of writing particular to a genre, for example, organization, analysis, or format, or more common editorial concerns such as punctuation or usage. The comments of the students we interviewed suggest that instructors at all levels and in all courses should provide more feedback to students on their writing and that they should provide more feedback during the writing process, when it can perform a formative rather than simply a summative role.

\section{A Final Word}

This article may seem to be shaped by the unwritten assumption that universities do have a role to play in preparing students for workplace writing. In fact, the role of universities in society is under constant interrogation: whether universities should be sites for "education" or "training" continues to be contested. Nonetheless, the reality is that the majority of students come to university for instrumental reasons-to get a degree and a set of skills that will enable them to get a job. We take the position that the choice between "education" and "training" is a false dichotomy; we maintain that students can be taught skills to survive in the world of work just as they are being taught how to question the social order and whose interests are being served by social institutions-including the very institution they are attending. If universities equip students with critical perspectives and theoretical knowledge but deprive them of 
practical skills in communication with which they can evoke social and practical change from within organizations, they are in fact disempowering students. We leave the last word to Sheila, who responded with the following insights when we asked her whether she thought professors should be providing students with more concrete training:

Yes I do, [but] I don't know that it's their place [now]. I mean professors are not really teachers; they're more researchers.... I think that the design of university maybe needs to change for something like Communications. You know, we're not back 200 years where you just came to think; the world is changing, maybe they need to change with the world and combine the practical with the theory. 


\section{Appendix: Questions for Semi-Structured Interviews}

1. How old are you?

2. What year of study and major?

3. Where is/was you current or most recent workterm? Previous workterms?

4. What is/was your position?

5. How much of your work time is spent writing?

6. What documents did you write?

7. Tell us about (or show us) a document you wrote on your workterm?

8. How much direction did you get from your supervisor about writing?

9. What kind of feedback did you receive from your supervisor about your writing?

10. Did you get feedback about grammar?

11. How different was the work place writing from your university writing experiences?

12. What surprised you about your work place writing experiences?

13. What writing courses did you take in university?

14. What kind of assignments did you do in these courses?

15. How well did you do in them?

16. Do you think your university education prepared you for the work place writing you did?

17. Should you have been better prepared?

18. What do you suggest should be changed or included?

19. Do your professors understand what will be required of you in the work place?

20. Do you think your professors should provide more concrete training?

21. Do you get sufficient feedback from your professors?

22 . What specific practical writing skills did you learn in your university courses?

23. How much writing did you do in your content area courses?

24. Did your workplace writing experience improve your academic writing?

25. In retrospect, is there anything you wish you had known before entering the workplace?

26. Have we missed anything you would like to tell us? 


\section{Footnotes}

1. Figure 1 was developed by Jo-Anne Andre, Barbara Schneider, Diane Douglas, and Betty Hersberger.

\section{References}

Anson, C. M., \& Forsberg, L. L. (1990). Moving beyond the academic community: Transitional stages in professional writing. Written Communication, 7, 200231.

Dias, P., Freedman, A., Medway, P. \& Paré, A. (1999). Worlds apart: Acting and writing in academic and workplace contexts. Mahwah, NJ: Lawrence Erlbaum Associates.

Driskill, L. (1989). Understanding the writing context in organizations. In M. Kogen, (Ed.), Writing in the business professions (pp. 125-145). Urbana, IL: National Council of Teachers of English.

Freedman, A. (1994). 'Do as I say': The relationship between teaching and learning new genres." In A. Freedman \& P. Medway, (Eds.). Genre and the new rhetoric (pp. 191-210). London: Taylor and Francis.

Freedman, A., Adam, C. \& G. Smart (1994). Wearing suits to class: Simulating genres and simulations as genre. Written Communication, 11, (2), 193-226.

Freedman, A. \& Adam, C. (1996). Learning to write professionally: "Situated learning" and the transition from university to professional discourse. Journal of Business and Technical Communication, 10, 395-427.

Glaser, B. \& Strauss, A. (1967). The discovery of grounded theory: Strategies for qualitative research. New York: Aldine.

Haswell, R. (1991). Gaining ground in college writing: Tales of development and interpretation. Dallas: Southern Methodist UP.

Leonard, D. J., \& Gilsdorf, J.W. (1990). Language in change: Academics' and executives' perceptions of usage errors. Journal of Business Communication, $27,137-158$.

Lutz, J. A. (1989). Writers in organizations and how they learn the image: Theory, research, and implications. In C. B. Matalene, (Ed.), Worlds of writing: Teaching and learning in discourse communities of work (pp. 113-135). New York: Random House. 
McKinnon, J. (1993). Becoming a rhetor: Developing writing ability in a mature, writing-intensive organization. In Spilka, R. (Ed.) Writing in the workplace: New research perspectives (pp. 41-55). Carbondale, Ill: Southern Illinois University Press.

Miller, C. (1994/1984). Genre as social action. In A. Freedman \& P. Medway, eds. Genre and the new rhetoric (pp. 23-42). London: Taylor and Francis.

Odell, L., \& Goswami, D. (Eds.). (1982). Writing in nonacademic settings. New York: Guilford.

Paré, A. \& Smart, G. (1994). Observing genres in action: Towards a research methodology. In A. Freedman \& P. Medway, (Eds.). Genre and the new rhetoric (pp. 146-154). London: Taylor and Francis.

Smart, G. (2000). Responding on-line to students' written work: When and how does it add value? Newsletter of the Canadian Association for the Study of Language and Learning, 18, 10-14.

Souther, J. (1963). What management wants in the technical report. Journal of English education, 52, 498-503. 